\title{
Effect of ATP and platelet-activating factor on intracellular calcium concentrations of cultured oviductal cells from cows
}

\author{
U. Tiemann ${ }^{1}$, P. Neels ${ }^{3}$, U. Küchenmeister ${ }^{2}$, H. Walzel ${ }^{3}$ and \\ M. Spitschak ${ }^{1}$ \\ ${ }^{1}$ Department of Reproductive Biology, and ${ }^{2}$ Muscle Biology and Growth, Research Institute for Biology of \\ Farm Animals, Dummerstorf D-18196, Germany; and ${ }^{3}$ Department of Medical Biochemistry, \\ University of Rostock, D-18057, Germany
}

\begin{abstract}
Oviductal endosalpingeal cells were mechanically isolated from heifers at different reproductive stages (cyclic: days 8-14, at oestrus: day 0 and pregnant: day 7) and cultured until $100 \%$ confluent. The cells were loaded with the $\mathrm{Ca}^{2+}$-sensitive fluorochrome fura-2/AM, and cytosolic free calcium $\left(\left[\mathrm{Ca}^{2+}\right]_{\mathrm{i}}\right)$ was monitored spectrofluorimetrically and by use of a microscope image analysis system. ATP $\left(400 \mu \mathrm{mol} \mathrm{l}^{-1}\right)$ evoked a prompt increase in $\left[\mathrm{Ca}^{2+}\right]_{i}$ in all cell preparations in both the presence or absence of extracellular $\mathrm{Ca}^{2+}$ when measured with the cuvette method. Single cell measurements using oviductal cells from cyclic heifers revealed a heterogeneous $\left[\mathrm{Ca}^{2+}\right]_{i}$ pattern in response to ATP, with some cells either failing to respond or reacting very slowly. Platelet-activating factor (PAF, $30 \mathrm{nmol}$ $\mathrm{l}^{-1}$ ) induced a rapid increase in $\left[\mathrm{Ca}^{2+}\right]_{i}$ especially in cells derived from cyclic and pregnant animals, but the effect was significantly less in cells from heifers at oestrus. The increase in $\left[\mathrm{Ca}^{2+}\right]_{\mathrm{i}}$ in bovine cells induced by PAF was reduced when extracellular calcium was depleted, indicating that the effect of PAF on $\left[\mathrm{Ca}^{2+}\right]_{\mathrm{i}}$ involves an influx from the extracellular space. Voltage-sensitive calcium channels do not appear to be involved in the influx of extracellular $\mathrm{Ca}^{2+}$ since verapamil had no effect on the PAF-induced increase in $\left[\mathrm{Ca}^{2+}\right]_{\mathrm{i}}$. The PAF receptor antagonist WEB 2086 inhibited the PAF-mediated effects on $\left[\mathrm{Ca}^{2+}\right]_{i}$.
\end{abstract}

\section{Introduction}

The oviduct is the site of many events involved in mammalian reproduction including gamete transport, fertilization, early embryonic development and embryo transport. During the oestrous cycle, at oestrus, and during early pregnancy, the oviduct undergoes changes in morphology that correlate with changes in ovarian steroid production. Morpho-functional changes have been convincingly demonstrated for oviductal ciliary activity, which plays a central role in ampullary transport of the ova or early embryo and may be under the control of steroids (Nozaki and Ito, 1987) and humoral factors, such as platelet-activating factor (PAF). Data from Hermoso and Villalon (1995) indicate that the ciliary beat of hamster oviductal ciliated cells in vitro are increased by the addition of physiological concentrations ( 20 or $200 \mathrm{nmol}^{-1}$ ) of PAF. PAF may mediate its action via specific receptors on oviductal cells, the existence of which was demonstrated in the oviductal membranes of rabbits during early pregnancy by Yang et al. (1992) using a radioligand-binding assay. The physiological role of endogenous PAF in oviduct function is still far from clear. PAF induces transient increases in $\left[\mathrm{Ca}^{2+}\right]_{\mathrm{i}}$, which might affect the functioning of many cell types, such as bovine cerebral microvascular endothelial cells (Lin and Rui, 1994) and

Revised manuscript received 22 March 1996 human endometrial HEC-1B cells (Ahmed et al., 1994). Calcium dynamics have not been determined directly in cultured bovine oviductal cells at different stages of the oestrous cycle. We therefore investigated the effect of PAF on cytosolic free calcium in endosalpingeal cells from bovine oviducts at days 8-14 of the oestrous cycle, at oestrus (day 0) and on day 7 of pregnancy using the fluorescent calcium indicator fura 2/AM. The intracellular calcium concentration was measured spectrofluorometrically and by microscopic image analysis of single cells. ATP was used as a positive control because the ATP-induced increase in $\left[\mathrm{Ca}^{2+}\right]_{i}$ has been reported in bovine oviduct epithelial cells (Cox and Leese, 1995) and in a variety of other cell types (Boynton et al., 1989; Fine et al., 1989; Geschwind et al., 1989).

\section{Materials and Methods}

\section{Materials}

Tissue culture supplies, platelet-activating factor (PAF), EGTA, Triton X-100, trypsin-EDTA solution and verapamil were obtained from Sigma Chemie $\mathrm{GmbH}$ (Deisenhofen). Phenol red-free RPMI 1640 and Tissue medium 199 (TCM 199) were supplemented with $1 \%(\mathrm{v} / \mathrm{v})$ antibiotic-antimycotic (ABAM) solution and $2 \mathrm{mmol}$ L-glutamine $\mathrm{1}^{-1}$. ATP and 
fura-2/acetoxymethylester (fura-2/AM), monoclonal antibodies to cytokeratin (no. 18) and vimentin, and fluoroscein isothiocyanate (FITC)-conjugated sheep anti-mouse IgG were obtained from Boehringer Mannheim Biochemicals (Mannheim). The PAF antagonist WEB 2086 was a gift from $\mathrm{H}$. Heuer (Boehringer Ingelheim KG, Germany). The antagonist was dissolved in 1 mol $\mathrm{HCl} \mathrm{l}^{-1}$ at a concentration of $300 \mathrm{mg}$ $\mathrm{ml}^{-1}$, rapidly neutralized with $1 \mathrm{~mol} \mathrm{NaOH}^{-1}$, and then diluted with saline.

Folicotropin (Spofa, Prague) was the source of FSH and the prostaglandin cloprostenol forte was purchased from Jenapharm (Jena).

\section{Animals}

Crossbred heifers between 20 and 22 months old and weighing between 350 and $380 \mathrm{~kg}$ were used. The following superovulatory treatment was applied: heifers were given two injections of FSH a day for 3 days (a total dose of $20 \mathrm{mg} \mathrm{FSH}$ ). Cloprostenol $(0.50 \mathrm{mg})$ was administered twice, $48 \mathrm{~h}(0.25 \mathrm{mg})$, and $58 \mathrm{~h}(0.25 \mathrm{mg})$, respectively, after the first FSH injection to regress the corpus luteum. Oestrus was determined by observation or palpation via the rectum or by both methods. Heifers were artificially inseminated twice, at 55 and $72 \mathrm{~h}$, respectively, after the first prostaglandin injection.

For heifers with a normal cycle (days 8-14), only reproductive tracts with a functional corpus luteum on one ovary were used.

Heifers were slaughtered ( 1 ) on the day of oestrus (day 0), (2) on day 7 of pregiancy or (3) between day 8 and day 14 of the cycle. Reproauctive tracts were removed immediately after slaughter and transported on ice to the laboratory. The oviducts and the uterine horns from heifers considered pregnant were flushed with PBS ( $\mathrm{pH} \mathrm{7.4)}$ to confirm the presence of embryos.

\section{Oviductal cell preparation and culture}

The isolation of oviductal endosalpingeal cells was carried out mechanically as described by Tiemann and Hansen (1995). Briefly, oviducts, collected from heifers on days $0,8-14$ of the cycle, and on day 7 of pregnancy, were transported at room temperature in Dulbecco's phosphate-buffered saline (PBS). Oviducts were separated from connective tissue and the fimbria removed. Each oviduct was then stripped of endosalpingeal cells by moving small forceps from the uterotubal junction towards the infundibulum. The endosalpingeal cells were extruded through the opening in the infundibulum and then washed three times in TM 199 supplemented with $1 \%$ $(v / v)$ ABAM. Cells from each heifer were cultured separately. Viability, determined by trypan blue exclusion, was $95 \%$. The oviductal cells consisting of clumps (approximately $2 \times 10^{6}$ cells $\mathrm{ml}^{-1}$, as determined by haemocytometer counting) were cultured in $80 \mathrm{~cm}^{3}$ tissue culture flasks (Greiner, Frickenhausen). The cells were cultured until 100\% confluent (after 8 days) in TCM 199 with $10 \%(\mathrm{v} / \mathrm{v}) \mathrm{FCS}$ and $1 \%(\mathrm{v} / \mathrm{v}) \mathrm{ABAM}$ at $37^{\circ} \mathrm{C}$ in humidified air $\left(5 \% \mathrm{CO}_{2}\right)$. The medium was changed every 2 days. After 8 days of culture, the adherent cells were washed gently twice with HBSS (Hank's balanced salt solution without
$\mathrm{Ca}^{2+}$ and $\left.\mathrm{Mg}^{2+}\right)$. Ten millilitres of trypsin-EDTA $(0.02-0.05 \%$, $\mathrm{w} / \mathrm{v}$ ) in HBSS was then added. After $20-30 \mathrm{~min}, 1 \mathrm{ml} 10 \%(\mathrm{v} / \mathrm{v})$ FCS was added to the cell suspension. The cells were washed twice with PBS and resuspended at $2 \times 10^{6} \mathrm{ml}^{-1}$ in RPMI 1640 medium.

\section{Immunofluorescent staining}

Oviductal cells were analysed by immunofluorescence using antibodies specific for epithelium (anticytokeratin) and fibroblasts (antivimentin) as described by Sun and Green (1978) to evaluate the cell types present in culture. Mechanically dispersed, endosalpingeal cells were grown on chamber slides (Nunc, Naperville, IL) in complete TCM 199 medium until reaching confluence. Cells were then washed in PBS, pH 7.4, fixed with acetone at $-20^{\circ} \mathrm{C}$, rinsed with PBS, incubated with FCS for $30 \mathrm{~min}$ at room temperature (to block non-specific binding sites), and then incubated with mouse anticytokeratin or antivimentin $\left(10 \mu \mathrm{g} \mathrm{ml} \mathrm{m}^{-1}\right.$ in PBS) for $60 \mathrm{~min}$ at $37^{\circ} \mathrm{C}$ (anticytokeratin) or room temperature (antivimentin). Cells were then washed with PBS, incubated with sheep antimouse IgG coupled to FITC $\left(12 \mu \mathrm{g} \mathrm{ml}^{-1}\right.$ in PBS containing $0.5 \%$ $(w / v)$ BSA), washed extensively in PBS and viewed for fluorescence using a Zeiss epifluorescence microscope.

\section{Loading with fura-2/AM}

The cells were loaded at room temperature (Malgaroli et al., 1987) by exposing them to fura-2/AM (final concentration, $2 \mu \mathrm{mol} 1^{-1}$ ) in RPMI 1640 medium under gentle shaking in the dark for $45 \mathrm{~min}$. The cells were centrifuged at $4^{\circ} \mathrm{C}$ and $500 \mathrm{~g}$ for $3 \mathrm{~min}$, and washed in a $\mathrm{Na}$-Hepes buffer, $\mathrm{pH} 7.4$, supplemented with $137 \mathrm{mmol} \mathrm{NaCl} \mathrm{l}^{-1}, 5 \mathrm{mmol} \mathrm{KCl} \mathrm{l}{ }^{-1}, 1 \mathrm{mmol}$ $\mathrm{Na}_{2} \mathrm{HPO}_{4} 1^{-1}, 1 \mathrm{mmol} \mathrm{CaCl}_{2} 1^{-1}, 0.5 \mathrm{mmol} \mathrm{MgCl}_{2} \mathrm{l}^{-1}$, $5 \mathrm{mmol}$ glucose $1^{-1}$ and $1 \mathrm{~g} \mathrm{BSA} \mathrm{^{-1 }}$. After three washing steps at $4^{\circ} \mathrm{C}$, the cells were resuspended in Na-Hepes buffer at a concentration of $2 \times 10^{6} \mathrm{ml}^{-1}$ and maintained on ice in the dark before fluorescence measurements.

\section{Measurement of intracellular calcium concentrations by spectrofluorimetry}

The fluorescence of the fura-2-loaded oviductal cells was measured with a spectrofluorimeter (Shimadzu RF-5001 PC) as described by Walzel et al. (1995). Briefly, $1.5 \mathrm{ml}$ fura-2-loaded cells were transferred to a thermostatic quartz cuvette at $37^{\circ} \mathrm{C}$ and the cells stirred continuously. The fluorescence was recorded for $5 \mathrm{~min}$ to reach an equilibrium at the temperature. Each agonist was added directly to the cell-containing cuvette. Excitation wavelengths of 339 and $380 \mathrm{~nm}$ were provided by a rotating filter wheel, and fluorescence was measured at $490 \mathrm{~nm}$. Graphical representations of $\left[\mathrm{Ca}^{2+}\right]_{i}$ were calculated by converting the ratio of 339:380 to $\left[\mathrm{Ca}^{2+}\right]_{i}$ using a $\mathrm{K}_{\mathrm{d}}$ of $224 \mathrm{nmol} \mathrm{I}^{-1}$ according the the equation

$$
\left[\mathrm{Ca}^{2+}\right]_{\mathrm{j}}=224 \times\left(R-R_{\min }\right) /\left(R_{\max }-R\right) \times \mathrm{Sf} 380 / \mathrm{Sb} 380,
$$

previously published by Grynkiewicz et al. (1985). $R_{\max }$ and $R_{\min }$ were evaluated in $1 \mathrm{mmol} \mathrm{Ca}^{2+}$-containing medium $\mathrm{l}^{-1}$ 
by lysing the cells with $0.5 \%$ Triton $X-100$ for $R_{\text {max }}$, followed by the addition of an excess of EGTA for $R_{\text {min }}$

For the studies in $\mathrm{Ca}^{2+}$-free buffer, EGTA was added to the fura-2-loaded cell suspensions (final concentration, $2 \mathrm{mmol} \mathrm{l}^{-1}$ ) before the addition of ATP or PAF.

Microscopic measurement of $\mathrm{Ca}^{2+} l_{\text {, }}$ and digital imaging analysis

Fifty microlitres of the fura-2-loaded cell suspension was pipetted onto a coverslip which was mounted in a (home-made) darkened microscope chamber. This chamber was placed on the stage of an inverted microscope (Zeiss Axiovert 135) which was coupled to an image analysis system (Photonics, Munich). The excitation wavelengths were 340 and $380 \mathrm{~nm}$ with an exposure time of $100 \mathrm{~ms}$. Thirty images were taken for $1 \mathrm{~min}$. With the $\times 20$ objective, between 50 and 150 cells could be observed. It was possible to measure a cluster of 3-10 cells in three of every four chosen regions or of single cells. After about $5 \mathrm{~s}$, the cells were stimulated with ATP (final concentration: $5 \mathrm{mmol} \mathrm{I}^{-1}$ ) or PAF (final concentration: $30 \mathrm{nmol} \mathrm{l}^{-1}$ ).

\section{Statistical analysis}

Each experiment ( $n$ ) represents a separate oviductal cell preparation. Aliquots of this were used for the determination of shifts in calcium concentrations induced by ATP or PAF. Data are expressed as means \pm SEM. The differences between means were evaluated by Student-Newman Keuls test. Values of $P<0.05$ were considered significant.

\section{Results}

\section{Characterization of oziductal cells by immunofluorescence}

Freshly isolated bovine oviductal cells were characterized by the presence of cilia on the epithelial cells. After attachment to the culture surface, the cilia could not be observed on the bovine oviduct cpithelial cells. Primary cultures reached confluency in approximately 8 days (Fig. Ia). Approximately $50 \%$ of oviductal cells dispersed mechanically and grown to confluence reacted positively with the antibody to cytokeratin, an epithelial cell marker (Fig. Ib). Similarly, about 50\% of the cells reacted with the antibody to vimentin, an intermediatc filament protein present in fibroblasts (Fig. 1c). Thus, the mechanically dispersed cell cultures grown on plastic contained a mixture of epithelial and fibroblast-like (stromal) cells. Cells did not fluoresce with non-immune serum (data not shown).

\section{Measurement of intracellutar calcium concentrations by} spectrofluorimetry

The effect of ATP on changes in $\left[\mathrm{Ca}^{2+}\right]_{i}$ in fura-2-loaded bovine endosalpingeal cells from the oviducts of animals at oestrus, cyclic animals or pregnant animals was measured by the cuvette method. ATP induced a rapid increase in $\left[\mathrm{Ca}^{2+}\right]_{i}$ which reached a maximum value within $30 \mathrm{~s}$, followed by a rapid decay (complete within $50 \mathrm{~s}$ ) to the basal value. The results of a representative experiment performed with
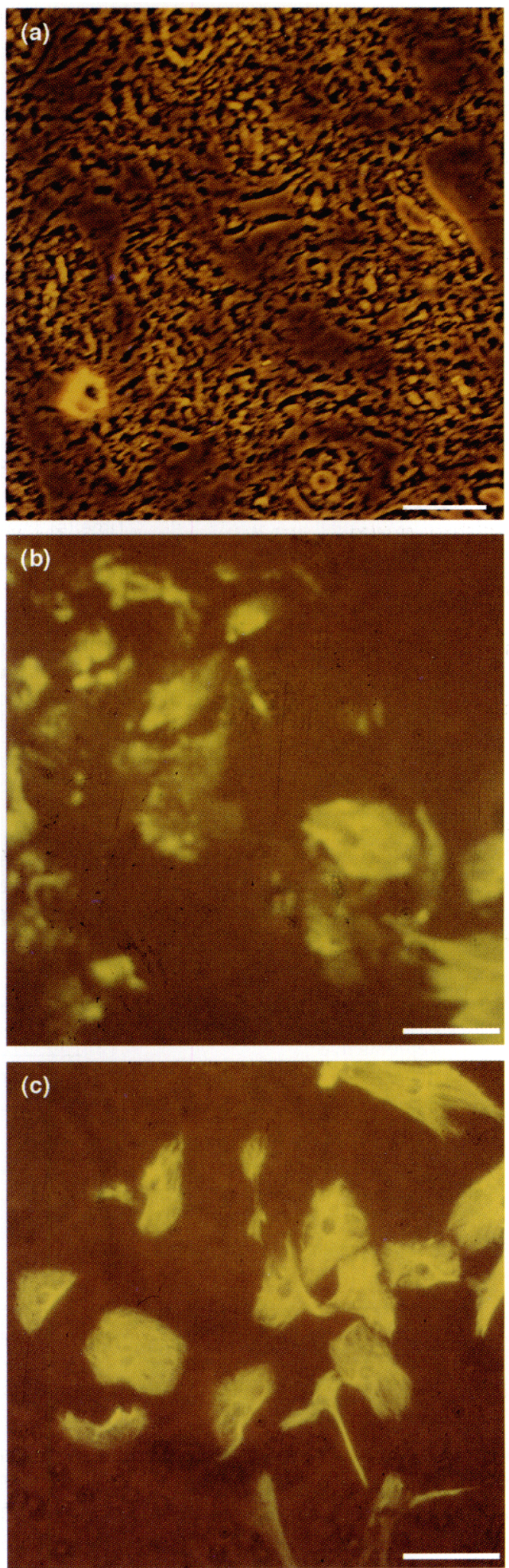

Fig. 1. Immunocytochemical characterization of bovine oviduct endosalpingeal cells cultured on plastic chamber slides for 8 days. (a) Phase contrast. The same field under green epi-illumination showing fluorescent staining for (b) cytokeratin and (c) vimentin within the cells. Scale bars represent (a) $100 \mu \mathrm{m}$ and (b) and (c) $25 \mu \mathrm{m}$. 

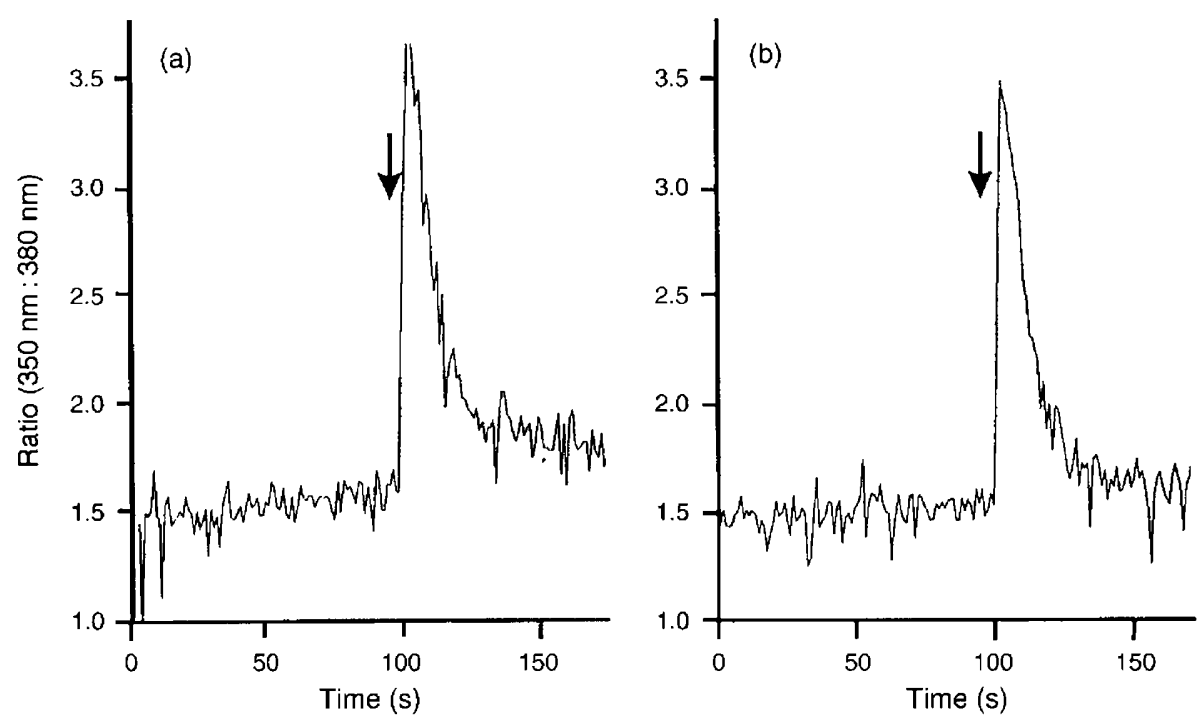

Fig. 2. The effect of extracellular ATP on intracellular $\mathrm{Ca}^{2+}$ concentrations in cultured oviductal cells derived from cyclic (days 8-14), oestrous (day 0), and pregnant (day 7) heifers. (a) Fura-2-loaded cells $\left(2 \times 10^{6} \mathrm{ml}^{-1}\right)$, derived from cyclic heifers, were suspended in basal salt solution ( $1.0 \mathrm{mmol} \mathrm{Ca}{ }^{2+} \mathrm{I}^{-1}$ ) and preincubated at $37^{\circ} \mathrm{C}$ for $5 \mathrm{~min}$ before the addition of ATP (final concentration, $400 \mu \mathrm{mol} \mathrm{l}^{-1}$ ). (b) In a second aliquot of cells, extracellular $\left[\mathrm{Ca}^{2+}\right\}$ was reduced by the addition of $2 \mathrm{mmol} \mathrm{EGTA} \mathrm{l}^{-1}$ (final concentration) 5 min before the addition of the ATP. Arrows indicate the addition of ATP. Results shown are typical of experiments that were repeated with similar results at least three times.

Table 1. Effect of ATP and platelet-activating factor (PAF) on the intracellular $\mathrm{Ca}^{2+}$ concentration $\left(\left[\mathrm{Ca}^{2+}\right]_{\mathrm{i}}\right)$ in the presence (without EGTA) or absence (with EGTA) of extracellular $\mathrm{Ca}^{2+}$ in fura-2-loaded oviductal cells from heifers at different reproductive stages measured by spectrofluorometry

\begin{tabular}{|c|c|c|c|c|c|c|c|}
\hline \multirow{3}{*}{$\begin{array}{l}\text { Reproductive } \\
\text { status }\end{array}$} & & \multicolumn{6}{|c|}{$\left[\mathrm{Ca}^{2+}\right]_{i}\left(\mathrm{nmol} \mathrm{l}^{-1}\right)$} \\
\hline & & \multicolumn{3}{|c|}{$\operatorname{ATP}\left(400 \mu \mathrm{mol} \mathrm{l}^{-1}\right)$} & \multicolumn{3}{|c|}{ PAF $\left(30 \mathrm{nmol} \mathrm{l}^{-1}\right)$} \\
\hline & & Mean & SEM & $n$ & Mean & SEM & $n$ \\
\hline Cyclic & - EGTA & 141 & $23^{\mathrm{a}}$ & 4 & 46 & $4^{\mathrm{b}}$ & 4 \\
\hline (days 8-14) & + EGTA & 159 & $20^{a}$ & 4 & 14 & $1^{\circ}$ & 4 \\
\hline Oestrus & - EGTA & 188 & $21^{\mathrm{a}}$ & 3 & 15 & $2^{c}$ & 3 \\
\hline (day 0$)$ & + EGTA & 182 & $18^{a}$ & 3 & 13 & $3^{c}$ & 3 \\
\hline Pregnant & - EGTA & 144 & $21^{\mathrm{a}}$ & 4 & 36 & $5^{b}$ & 4 \\
\hline$($ day 7$)$ & + EGTA & 154 & $13^{\mathrm{a}}$ & 4 & 12 & $1^{\mathrm{c}}$ & 4 \\
\hline
\end{tabular}

Each value presents mean \pm SEM. ${ }^{\text {atc }} V$ alues with the same letters within the same column are not significantly different $(P>0.05)$.

fura-2-loaded oviductal cells from cyclic (days 8-14), oestrus (day 0), and pregnant (day 7) cows are shown (Fig. 2). Maximum concentrations of $\left[\mathrm{Ca}^{2+}\right]_{i}$ ranged from $14 \mathrm{I}$ to $188 \mathrm{nmol}^{-1}$ (11 separate experiments, and were independent of reproductive stage (Table 1 ). When fura-2-loaded cells were incubated in the absence of extracellular calcium (that is, in the presence of $2 \mathrm{mmol}$ EGTA $\mathrm{l}^{-1}$, final concentration), the addition of $400 \mu \mathrm{mol} \mathrm{ATP} \mathrm{I}^{-1}$ produced a peak similar to that observed in the presence of extracellular $\mathrm{Ca}^{2+}\left(1.0 \mathrm{mmol} \mathrm{I}^{-1}\right)$. This finding indicates that an increase in $\left[\mathrm{Ca}^{2+}\right]_{i}$ induced by ATP is derived from intracellular sources.
The $\mathrm{Ca}^{2+}$-mobilizing effects of PAF were measured in aliquots of the same cell suspensions used in the experiments described above. With the cuvette method, the addition of PAF ( $30 \mathrm{nmol} \mathrm{L}^{-1}$, final concentration) to the fura-2-loaded oviductal cells taken from cows at different stages of the reproductive cycle resulted in an increase of fluorescence, indicative of increased $\left[\mathrm{Ca}^{2+}\right]_{i}$, but in different manner to that obtained with ATP. PAF stimulated a monophasic rise in $\left[\mathrm{Ca}^{2+}\right]_{i}$ which returned to basal values within $1 \mathrm{~min}$. The $\left[\mathrm{Ca}^{2+}\right]_{\mathrm{i}}$ increased from a basal value of $8 \pm 2 \mathrm{nmol} \mathrm{l}^{-1}(n=11)$ to $36 \pm 5 \mathrm{nmol}$ $1^{-1}(n=4)$ in cells from pregnant heifers, to $46.0 \pm 4 \mathrm{nmol} \mathrm{I}^{-1}$ 


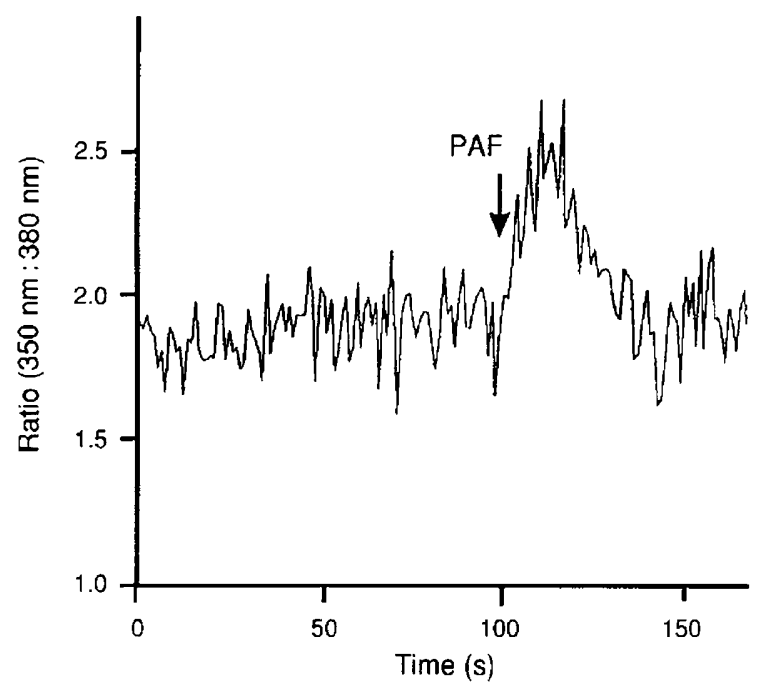

Fig. 3. Effect of adding the calcium-channel blocker verapamil (final concentration, $100 \mathrm{~mol} \mathrm{I}^{-1}$ ) to fura-2-loaded cultured oviductal cells derived from cyclic heifers (days 8-14) $100 \mathrm{~s}$ before the addition of platelet-activating factor (PAF) (final concentration, $30 \mathrm{nmol}^{-1}$ ) in the presence of $\mathrm{Ca}^{2+}$-containing buffer.

$(n=4)$ in cells from cyclic cows; whereas in cells from cows at oestrus there was only a slight effect $\left(15 \pm 2 \mathrm{nmol} \mathrm{l}^{-1}\right.$ : $n=3$ ). The differences in $\mathrm{Ca}^{2+}$ mobilization between cyclic and pregnant cows compared with heifers at oestrus were significant $(P<0.05)$. To establish whether the response of PAF was due to $\mathrm{Ca}^{2+}$ release from intracellular stores or the result of influx from extracellular spaces, 2 mmol EGTA $\mathrm{l}^{-\mathrm{I}}$ was added before the addition of $30 \mathrm{nmol}$ PAF ${ }^{-1}$. $\mathrm{Ca}^{2+}$ chelation to EGTA resulted in the inhibition of the response of oviductal cells from cyclic and pregnant cows to PAF (Table 1), suggesting that the increased $\left[\mathrm{Ca}^{2+}\right]_{\mathrm{i}}$ was derived largely from an extracellular source. In cells derived from animals at oestrus, the $\left[\mathrm{Ca}^{2+}\right]_{\mathrm{i}}$ was in the same range after incubation in a medium with or without $\mathrm{Ca}^{2+}$.

Preincubation of the cells from cyclic animals with the voltage-sensitive calcium channel blocker verapamil $(100 \mu \mathrm{mol}$ $\mathrm{I}^{-1}$, final concentration) in the $\mathrm{Ca}^{2+}$-containing medium did not affect the increase in $\left[\mathrm{Ca}^{2+}\right]_{i}$ induced by PAF (Fig. 3).

To assess the specificity of the PAF receptor, experiments were conducted in the presence of the specific PAF receptor antagonist WEB 2086 (Casals-Stenzel et al., 1987) using fura-2-loaded oviductal cells from cyclic heifers. The increase in $\left[\mathrm{Ca}^{2+}\right]_{\mathrm{i}}$ evoked by PAF in the presence of external $\mathrm{Ca}^{2+}$ was completely blocked by the addition of WEB 2086 (final concentration, $30 \mu \mathrm{mol} \mathrm{I} I^{-1}$ ), indicating that the response is mediated by the PAF receptor (Fig. 4). When the concentration of WEB 2086 was reduced to $15 \mu \mathrm{mol} 1^{-1}$, the inhibitory effect was diminished to about $30 \%$ (data not shown).

\section{Microscopic measurement of intracellular $\left[\mathrm{Ca}^{2+}\right]$ by digital imaging analysis}

ATP (final concentration, $5 \mathrm{mmol} \mathrm{l}^{-1}$ ) was added to fura-2-loaded oviductal cells from cyclic heifers and the data
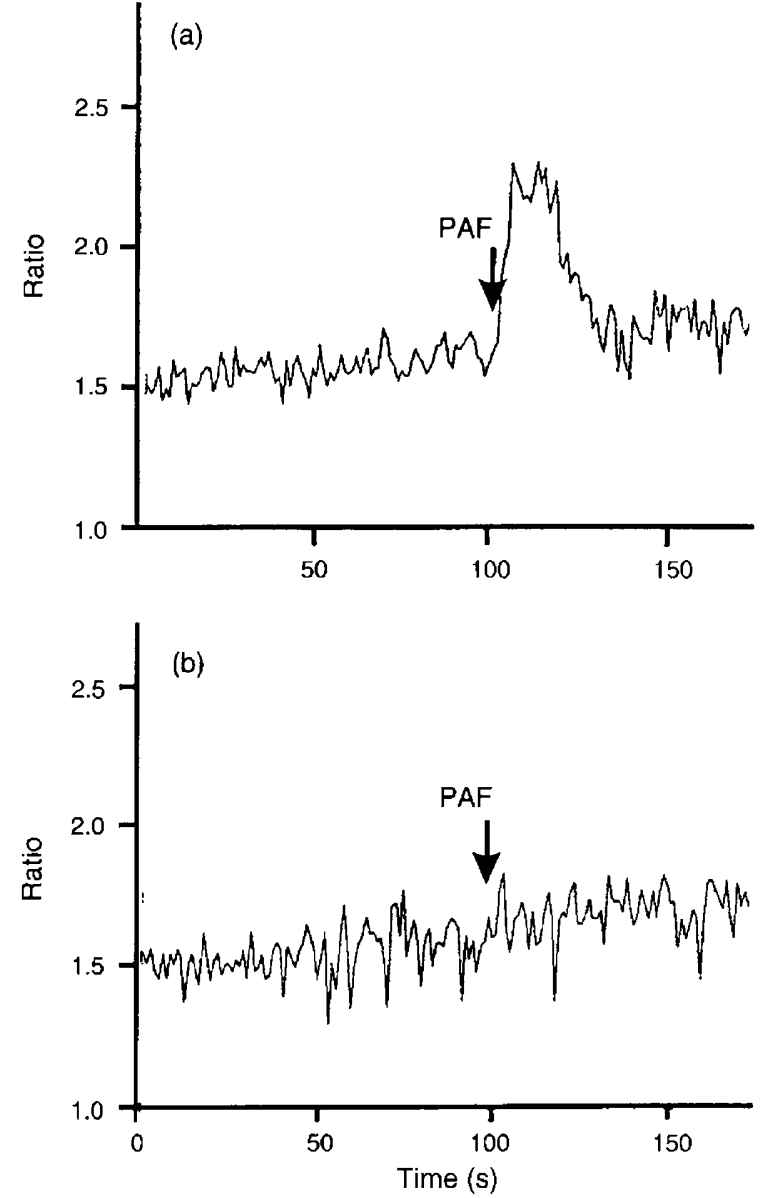

Fig. 4. Effect of the platelet-activating factor (PAF) antagonist WEB 2086 on the PAF-induced increase in intracellular $\mathrm{Ca}^{2+}$ in fura-2loaded cultured oviductal cells from cyclic heifers (days 8-14). The cells were incubated (a) without or (b) with WEB 2086 (final concentration, $30 \mu \mathrm{mol} \mathrm{l}^{-1}$ ) for 2 min before the addition of PAF (final concentration, $30 \mathrm{nmol} \mathrm{l}^{-1}$ ) in the presence of $\mathrm{Ca}^{2+}$-containing buffer (1.0 $\left.\mathrm{mmol} \mathrm{l}^{-1}\right)$.

subjected to digital imaging analysis. Figure 5 provides a visual impression of the cellular heterogeneity in the $\left[\mathrm{Ca}^{2+}\right]_{\mathrm{i}}$ responses of individual cells. Some cells showed a comparatively rapid response after the addition of the agonist, while others responded more slowly. A third subset of the cells failed to respond. Interestingly, there were differences between the $\left[\mathrm{Ca}^{2+}\right]_{i}$ transients of the cells. For example, the cell marked ' 1 ' showed an initial increase after $10 \mathrm{~s}$, reaching maximum fluorescence at $20 \mathrm{~s}$, whereas cell ' 5 ' responded with maximum fluorescence $10 \mathrm{~s}$ after the challenge. Cells ' 2 ' and ' 4 ' were either insensitive to ATP stimulation, or had possibly failed to load sufficient fura-2/AM fluorophore to enable the increase in intracellular $\mathrm{Ca}^{2+}$ to be visualized. The quantitative changes in $\left[\mathrm{Ca}^{2+}\right]_{\mathrm{i}}$ in the selected cells over time are shown (Fig. 5f). The differences in response of intracellular $\left[\mathrm{Ca}^{2+}\right]$ in oviductal cells from cyclic heifers after the addition of ATP (final concentration, $5 \mathrm{mmol} \mathrm{l}^{-1}$ ) and PAF (final concentration, $30 \mathrm{nmol}$ $\mathrm{1}^{-1}$ ) in $1.0 \mathrm{mmol} \mathrm{Ca}{ }^{2+} \mathrm{l}^{-1}$ are shown (Fig. 6). The results confirm the data obtained by the cuvette method with the response to PAF being smaller than that obtained with ATP. 

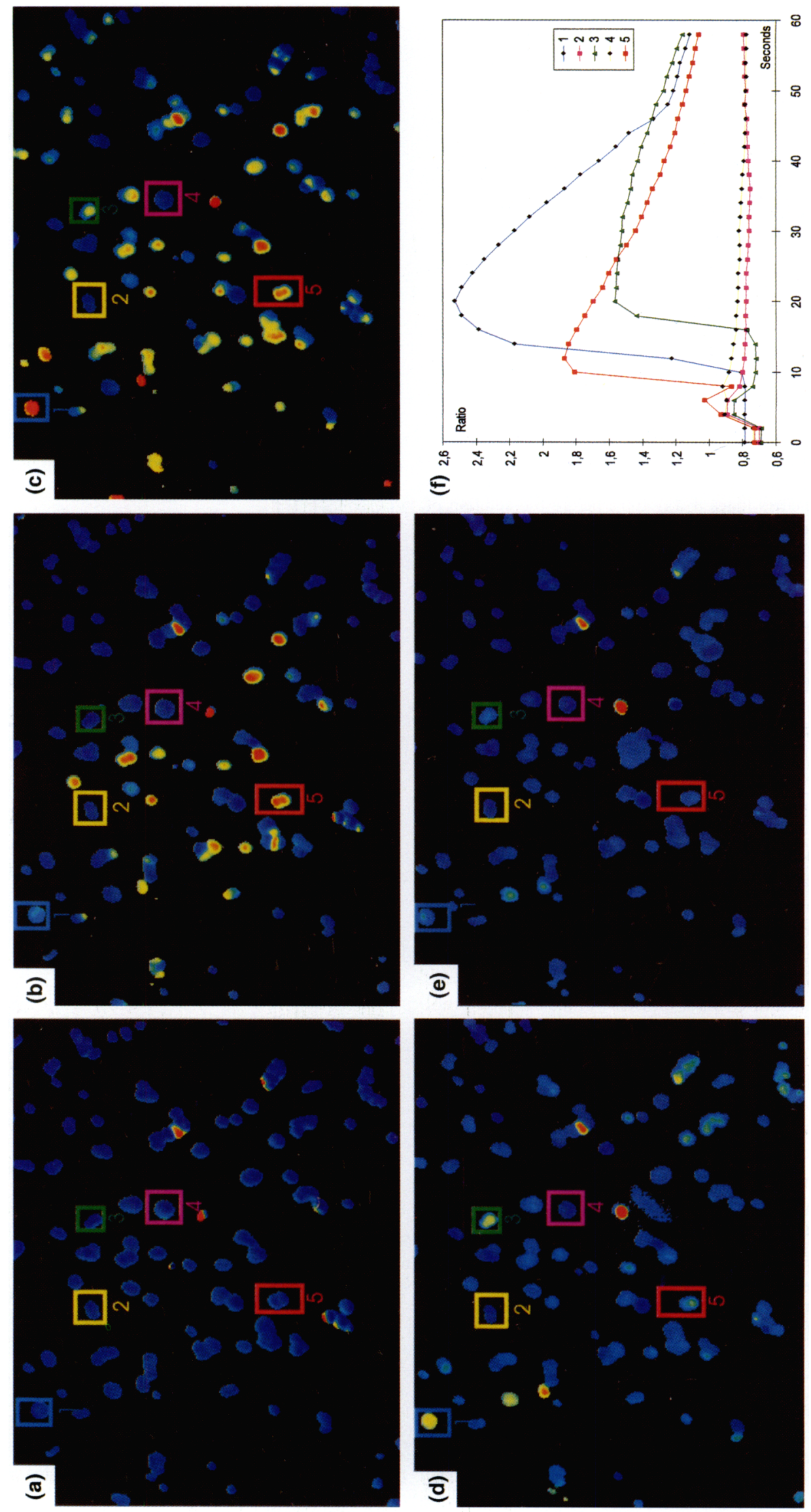

Downloaded from Bioscientifica.com at 04/26/2023 02:22:22AM 


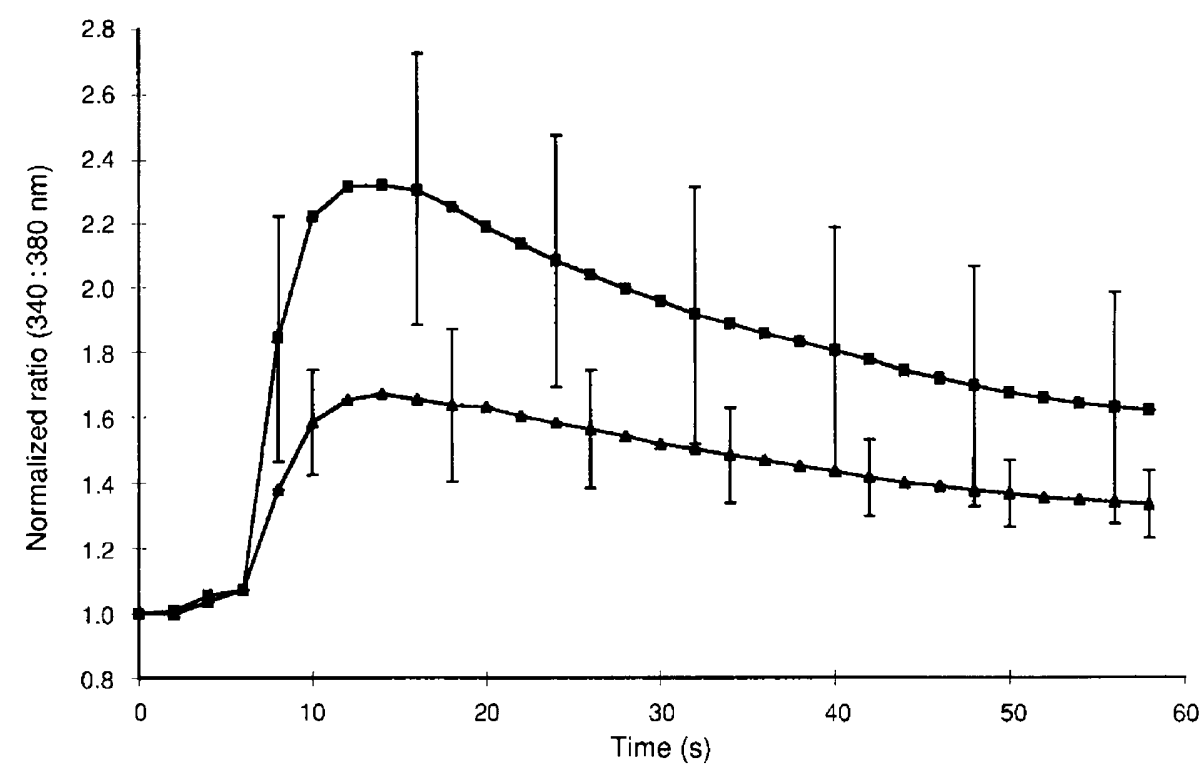

Fig. 6. The effect of extracellular ATP $(\boldsymbol{\square})$ and platelet-activating factor (PAF) ( $\mathbf{\Delta}$ ) on intracellular $\mathrm{Ca}^{2+}$ concentrations in fura-2-loaded oviductal cells derived from cyclic heifers (days 8-14), as measured in a microscope system in the presence of $1.0 \mathrm{mmol} \mathrm{Ca}{ }^{2+} \mathrm{I}^{-1}$. Values are expressed as means \pm SEM of five clusters of cells from five animals.

\section{Discussion}

In the experiments reported here bovine oviductal cells were prepared by mechanical disruption and then cultured on plastic. In primary cultures, the presence of stromal and epithelial cells was confirmed by immunohistochemical staining. After an additional cell purification step (Rosselli et al., 1994), approximately $94 \%$ of the bovine oviductal epithelial cells stained positive with anticytokeratin.

The study reported here demonstrates that the addition of ATP $\left(400 \mu \mathrm{mol} \mathrm{l}^{-1}\right)$ to cultured endosalpingeal cells of the bovine oviduct from cyclic (days 8-14), oestrous (day 0), and pregnant (day 7) animals results in a sharp increase in $\left[\mathrm{Ca}^{2+}\right]_{\mathrm{i}}$. Spectrofluorimetric experiments, in which the influx of extracellular calcium was blocked by calcium chelation to EGTA, showed that the rapid rise of $\left[\mathrm{Ca}^{2+}\right]_{\mathrm{i}}$ was independent of extracellular calcium and consequently, was a result of the release of calcium from intracellular stores, such as the endoplasmic reticulum or the calciosome. This result agrees with the data from Boynton et al. (1989) who found that extracellular ATP evoked a prompt increase in $\left[\mathrm{Ca}^{2+}\right]_{i}$ in both the presence and absence of extracellular $\mathrm{Ca}^{2+}$.

In certain cell types, the increase in $\left[\mathrm{Ca}^{2+}\right]_{\mathrm{i}}$ leads to specific responses such as DNA synthesis (Gregory and Kern, 1978; Humes and Cieslinski, 1991; Popper and Batra, 1993). We have confirmed that DNA synthesis, measured by the incorporation of $\left[^{3} \mathrm{H}\right]$ thymidine into cultured oviductal cells from cyclic heifers was increased two-fold by the addition of ATP (final concentration $400 \mu \mathrm{mol} \mathrm{l}^{-1}$ to $5 \mathrm{mmol} \mathrm{l}^{-1}$ ) compared with synthesis by controls (data not shown). ATP has been shown to act by binding to specific $\mathrm{P}_{2}$-purinoreceptors, leading to the hydrolysis of phosphoinositides and the production of Ins $(1,4,5) \mathrm{P}_{3}$, which in turn mediates calcium mobilization (Gordon, 1986). Cells derived from heifers at different reproductive stages that reacted positively to the addition of ATP with a release of $\mathrm{Ca}^{2+}$ from intracellular stores were used to determine whether binding of PAF to oviductal cells was associated with alterations in intracellular calcium concentration. PAF was found to be an inducer of calcium mobilization. However, the character of the response to PAF was different to that induced by ATP and was related to reproductive stage. In cells derived from cyclic and pregnant heifers, calcium mobilization was rapid, in contrast to that of animals at oestrus, which showed a considerable reduction in the PAFinduced increase in $\left[\mathrm{Ca}^{2+}\right]_{j}$. Differences in the responsiveness of the cells to PAF may be due to variations in the actions of PAF receptors; however, data on the cell membranes of the oviduct are scarce. Yang et al. (1992) showed that rabbit oviductal membranes bind tritiated PAF on days 3 and 6 of pregnancy. PAF is expressed at the pre-implantation stage of sheep embryos (Battye et al., 1991), and there is indirect evidence (the presence of thrombocytopenia in pregnant cows) that PAF may be produced by the conceptus on days 8-17 (Hansel et al., 1989). PAF concentrations in the ovaries of rats (Abisogun et al., 1989; Espey et al., 1989) and mice (Kikukawa et al., 1990) decrease during ovulation. This decrease in PAF at ovulation could explain why PAF induced only a small increase in $\left[\mathrm{Ca}^{2+}\right]_{\mathrm{i}}$ in oviductal cells obtained from heifers at oestrus with the

Fig. 5. Temporal differences in the changes in intracellular $\mathrm{Ca}^{2+}$ concentrations of fura-2-loaded cultured oviductal cells derived from cyclic heifers (days 8-14) after stimulation with ATP (final concentration, $5 \mathrm{mmol} \mathrm{1}^{-1}$ ). (a) Just before stimulation; (b) $4 \mathrm{~s}$ after stimulation; (c) $20 \mathrm{~s}$ after stimulation; (d) $40 \mathrm{~s}$ after stimulation and, (e) $60 \mathrm{~s}$ after stimulation. (f) The kinetics of the marked cells. 
reduced concentration of the ligand influencing the number of PAF-receptors on the oviductal cells.

The biological significance of the increase in $\left[\mathrm{Ca}^{2+}\right]_{\mathrm{i}}$ induced by PAF in bovine oviductal cells from cyclic and pregnant animals remains unclear at this stage. The activity of phospholipase $\mathrm{A}_{2}$ is dependent on $\mathrm{Ca}^{2+}$ (Channon and Leslie, 1990; Ahmed and Smith, 1992). The PAF-induced increase in $\left[\mathrm{Ca}^{2+}\right]_{i}$ may be an important step in signal transduction that exerts its biological effects on oviductal cells. Furthermore, PAF has an influence on the ciliary activity of oviductal cells (Hermoso and Villalon, 1995), and together with the contraction of the myometrium, is responsible for the oviductal transport of ova or embryo. Montrucchio et al. (1986) reported that PAF stimulates the contraction of guinea-pig and human myometria. Zhu et al. (1992) confirmed this result and showed that PAF at concentrations between $10^{-12}$ and $10^{-10} \mathrm{~mol}^{-1}$ caused a two-fold increase in intracellular $\left[\mathrm{Ca}^{2+}\right]$ and in the phosphorylation of myosin light chains.

Our experiments demonstrate that PAF induces an increase in $\left[\mathrm{Ca}^{2+}\right]_{i}$ consisting of a rapid response which is abolished by a $\mathrm{Ca}^{2+}$-free solution. The result indicates that the response is mostly dependent on $\mathrm{Ca}^{2+}$ influx from extracellular sources and is in agreement with the results of Kondo et al. (1994) in bovine tracheal epithelial cells. In these cells, the $\mathrm{Ca}^{2+}$ influx from the extracellular solution is a major source of the increase in calcium induced by PAF. Voltage-sensitive calcium channels do not appear to be involved in the influx of extracellular $\mathrm{Ca}^{2+}$ because the voltage-sensitive calcium channel antagonist verapamil had no effect on the PAFinduced increase in $\left[\mathrm{Ca}^{2+}\right]_{\mathrm{i}}$. This finding is consistent with observations in cultured bovine cerebral microvascular endothelial cells (Lin and Rui, 1994).

The increase in $\left[\mathrm{Ca}^{2+}\right]_{\mathrm{i}}$ induced by PAF is mediated by the activation of PAF receptors, since pretreatment of cells with the specific receptor antagonist WEB 2086 inhibited the response suggesting a specific receptor mechanism, in agreement with previous reports in endothelial cells (Hirafuji et al., 1988; Gardner et al., 1993).

The results obtained with spectrofluorometry of cell suspensions, using fura-2AM as the $\left[\mathrm{Ca}^{2+}\right]_{i}$ probe, represent an average response of the cells in suspension. A microscopic analysis was therefore made to determine the $\left[\mathrm{Ca}^{2+}\right]_{\mathrm{i}}$ response at the single cell level. Although preliminary in nature and subject to a number of problems associated with this methodology (in particular the possible heterogeneity of cellular dye loading and intracellular dye localization) our experiments indicated that ATP induced an increase in $\left[\mathrm{Ca}^{2+}\right]_{\mathrm{i}}$ in most, but not all oviductal cells. Our result agrees with observations on rat liver epithelial cells by Boynton et al. (1989). An explanation for the asynchronous response of our cell population could be that the medium was not stirred and therefore the diffusion times for the fluorophore differed. Another reason could be the heterogeneity of the cell suspension which contained a mixture of epithelial and stromal cells.

In conclusion, the present study demonstrates that a biologically relevant concentration of PAF induces a rapid and transient $\left[\mathrm{Ca}^{2+}\right]_{\mathrm{i}}$ mobilization in cultured endosalpingeal cells from the oviduct of cyclic and pregnant heifers via receptoroperated $\mathrm{Ca}^{2+}$ channels, whereas mobilization was diminished in cells obtained from heifers at oestrus.

\section{References}

Abisogun AO, Braquet P and Tsafriri A (1989) The involvement of platelet activating factor in ovulation Science $243381-383$.

Ahmed A and Smith SK (1992) Platelet-activating factor stimulates phospholipase C activity in human endometrium Journal of Cellular Physiology 152 $207-214$

Ahmed A, Sage SO, Plevin R, Shoaibi MA, Sharkey AM and Smith SK (1994) Functional platelet-activating factor receptors linked to inositol lipid hydrolysis, calcium mobilization and tyrosine kinase activity in the human endometrial HEC-IB cell line Journal of Reproduction and Fertility 101 459-466

Battye KM, Ammit AJ, O'Neill C and Evans C (1991) Production of plateletactivating factor by pre-implantation sheep embryos Journal of Reproduction and Fertility 93 507-514

Boynton Al, Cooney RV, Hill TD, Nilsson T, Arkhammer P and Berggen P-O (1989) Extracellular ATP mobilises intracellular $\mathrm{Ca}^{2+}$ in $\mathrm{T} 51 \mathrm{~B}$ rat liver epithelial cells: a study involving single cell measurements Experimental Cell Research 181 245-255

Casals-Stenzel J, Muaceivic G and Weber KH (1987) Pharmacological actions of WEB 2086, a new specific antagonist of platelet-activating factor Journal of Pharmacology and Experimental Therapeutics 241 974-981

Channon JY and Leslie CC (1990) A calcium-dependent mechanism for associating a soluble arachidonyl-hydrolyzing phospholipase A2 with membrane in the macrophage cell line RAW 264.7 Journal of Biological Chemistry 265 5409-5413

Cox CI and Leese HJ (1995) Effect of purinergic stimulation of intracellular calcium concentration and transepithelial potential differences in cultured bovine oviduct cells Biology of Reproduction 52 1244-1249

Espey LL, Tanaka N, Woodard DS, Harper JK and Okamura H (1989) Decrease in ovarian platelet-activating factor during ovulation in the gonadotropinprimed immature rat Biology of Reproduction 40 104-110

Fine J, Cole P and Davidson JS (1989) Extracellular nucleotides stimulate receptor-mediated calcium mobilization and inositol phosphate production in human fibroblasts Biochemical Journal $263371-376$

Gardner CR, Laskin, JD and Laskin DL (1993) Platelet-activating factor-induced calcium mobilization and oxidative metabolism in hepatic macrophages and endothelial cells Journal of Leukocyte Biology 53 190-196

Geschwind JF, Hiriart M and Glennon MC (1989) Selective activation of $\mathrm{Ca}^{2+}$ influx by extracellular ATP in a pancreatic $\beta$-cell line (HIT) Biochimica et Biophysica Acta 1012 107-115

Gordon JL (1986) Extracellular ATP: effects, sources and fate Biochemical Journal $233309-319$

Gregory S and Kern M (1978) Adenosine and adenine nucleotides are mitogenic for mouse thymocytes Biochemical and Biophysical Research Communications 83 1111-1116

Grynkiewicz G, Poenie M and Tsien RY (1985) A new generation of $\mathrm{Ca}^{2+}$ indicators with greatly improved fluorescence properties Journal of Biological Chernistry $2603440-3450$

Hansel W, Stock A and Battista PJ (1989) Low molecular weight lipid-soluble luteotrophic factors produced by conceptuses in cows Joumal of Reproduction and Fertility Supplement 37 11-17

Hermoso MA and Villalon MJ (1995) Embryo-secreted factors increase the frequency of ciliary beat of hamster oviductal ciliated cells in vitro Biology of Reproduction 52 SI 180

Hirafuji M, Maeyama K, Watanabe T and Ogura $Y$ (1988) Transient increases of cytosolic free calcium in cultured human vascular endothelial cells by platelet-activating factor Biochemical and Biophysical Research Communications $154910-917$

Humes DH and Cieslinski DA (1991) Adenosine triphosphate stimulates thymidine incorporation but does not promote cell growth in primary culture of renal proximal tubule cells Renal Physiology and Biochemistry 14 $253-258$

Kikukawa Y, Ishikawa M, Sengoku K and Shimizu T (1990) The role of platelet-activating factor in ovulation Acta Obstetrica et Gynaecologica Japonica 6 573-578

Konda M, Tamaoki J, Isono K, Takeuchi S, Ozawa Y, Chiyotani A and Konno K (1994) Effect of platelet-activating factor on intracellular free calcium in cow tracheal epithelium American Journal of Respiratory Cell and Molecular Biology $10278-283$ 
Lin A-Y and Rui Y-Ch (1994) Platelet-activating factor induced calcium mobilization and phosphoinositide metabolism in cultured bovine cerebral microvascular endothelial cells Biochimica et Biophysica Acta 1224 323-328

Malgaroli A, Milani D, Meldolesci J and Pozzan T (1987) Fura-2 measurements of cytosolic free $\mathrm{Ca}^{2+}$ in monolayers and suspensions of various types of animal cells Journal of Cell Biology 105 2145-2155

Montrucchio G, Alloatti G, Tetta C, Roffinello C, Emanualli G and Camussi G (1986) In vitro contractile effect of platelet-activating factor on guinea pig myometrium Prostaglandins 32 539-554

Nozaki $M$ and Ito $Y$ (1987) Changes in physiological properties of rabbit oviduct by ovarian steroids American Journal of Physiology 252 Rio59R1065

Popper LD and Batra S (1993) Calcium mobilization and cell proliferation activated by extracellular ATP in human ovarian tumor cells Cell Calcium 14 $209-218$

Rosselli M, Imthurn B, Macas E and Keller PJ (1994) Endothelin production by bovine oviduct epithelial cells Journal of Reproduction and Fertility 101 27-30
Sun T-T and Green H (1978) Immunofluorescent staining of keratin fibers in cultured cells Cell 14 469-476

Tiemann U and Hansen PJ (1995) Steroidal and growth factor regulation of $\left[{ }^{3} \mathrm{H}\right]$ thymidine incorporation by cultured endosalpingeal cells of the bovine oviduct In Vitro Cellular and Developmental Biology A 31 640-645

Walzel H, Hirabayashi J, Kasai K-I, Brock J and Neels P (1995) Cell calcium signalling induced by endogenous lectin carbohydrate interaction in the Jurkat T cell line Glycoconjugate Journal 12 I-7

Yang Y-O, Kudolo GB and Harper MJK (1992) Binding of platelet-activating factor to oviductal membranes during early pregnancy in the rabbit Journal of Lipid Mediators 5 77-96

Zhu Y-P, Word RN and Johnston JM (1992) The presence of PAF-binding sites in human myometrium and its role in uterine contraction American Journal Obstetrics and Gynecology $166 \quad 1222-1227$ 